\title{
Detection of Toxoplasma gondii DNA in Sheep and Goat Milk in Northwest of Iran by PCR-RFLP
}

\author{
Mousa Tavassoli ${ }^{1,}$, Bijan Esmaeilnejad ${ }^{1}$, Farnaz Malekifard ${ }^{1}$, Ali Soleimanzadeh ${ }^{2}$, Mahdi \\ Dilmaghani $^{3}$
}

${ }^{1}$ Department of Pathobiology, Faculty of Veterinary Medicine, Urmia University, Urmia, IR Iran

${ }^{2}$ Department of Clinical Sciences, Faculty of Veterinary Medicine, Urmia University, Urmia, IR Iran

${ }^{3}$ Department of Microbiology, Faculty of Veterinary Medicine, Urmia University, Urmia, IR Iran

${ }^{*}$ Corresponding author: Mousa Tavassoli, Department of Pathobiology, Faculty of Veterinary Medicine, Urmia University, P.O. Box 1177, Urmia, IR Iran. Tel: +98-4412972654, Fax: +984412770508, E-mail: mtavassoli2000@yahoo.com.

Received: September 17, 2012; Revised: January 19, 2013; Accepted: January 27, 2013

\begin{abstract}
Background: Toxoplasmosis is a widespread disease in humans and many other species of warm-blooded animals. Among livestock animals, sheep and goat are more widely infected by Toxoplasma gondii. This parasite is a major cause of abortion, with significant economic losses for sheep and goat breeders.

Objectives: The polymerase chain reaction(PCR) method was employed to detect of the T.gondii DNA in the milk of sheep and goats based on its B1 gene.

Materials and methods: A total of 625 milk samples were collected from 345 sheep and 280 goats from randomly selected flocks of NorthWest of Iran.

Results: Of 625 examined milk samples, 19 animals (3.04\%) yielded a specific T. gondii B1 fragment (529 bp), of which T. gondii was detected in 16 (4.63\%) sheep and 3 (1.07\%) goat milk samples. Restriction fragment length polymorphism (RFLP) analysis of the PCR products of $T$. gondii with AluI restriction enzyme produced only one distinct pattern among all positive samples, which indicates that one RFLP profile of T. gondii exists in the study area.

Conclusions: Presence of T. gondii DNA in the milk of sheep and goats raises the possibility that this parasite is transmitted through consumption of raw milk. Since sheep and goats are important milk sources in Iran, there is a high risk of contamination through milk from these hosts due to their susceptibility to infection. Further studies are required on milk producing animals to implement effective control strategies against toxoplasmosis.
\end{abstract}

Keywords: Toxoplasma gondii; Milk; Sheep; Goat; Iran

\section{Background}

Toxoplasma gondii is an intracellular protozoan parasite causing disease in human, small ruminant and other warm blooded mammals (1). Pig, Cat, Sheep and goat are the most infected domestic animal by this parasite (2). This parasite is a major cause of abortion, with significant economic losses for sheep and goat breeders $(3,4)$. Besides its vertical transmission, consumption of undercooked meat, drinking water and unpasteurized milk contaminated with oocysts or tissue cysts of $T$. gondii can result in the horizontal transmission $(2,5)$. If oocysts get ingested by a human or domestic animal, the parasite undergoes asexual reproduction, characterised by rapidly dividing tachyzoites and the less-rapidly dividing bradyzoites, which encyst in the brain, heart, and other tissues and remain for the host's lifetime (6). Food animals including pigs, sheep, and goats have the highest rate of Toxoplasma tissue cysts in comparison with other animals. The economic losses due to toxoplasmosis in livestock are still quite high in many countries (7).

Toxoplasmosis results in significant reproductive and economic losses in animals as well as public health concerns as consumption of contaminated meat and milk damage the human health and can facilitate zoonotic transmission (8). Prevalence of T. gondii in sheep and goats is very high due to the continuous contamination of pastures by T. gondii oocysts and that makes this parasite a common infectious agent among these animals. Since sexual reproduction of $T$. gondii can be accomplished only in felines (9), due to the release of oocysts into the environment, the presence of cats as the definitive hosts is an important risk factor for T. gondii infection in small ruminants and considerable in the epidemiological chain regarding the transmission of parasites to sheep and goats (10).

Tachyzoit of T. gondii has been found in the milk of sev-

Implication for health policy/practice/research/medical education:

Presence of Toxoplasma gondii DNA in the milk of sheep and goats raises the possibility that this parasite can be transmitted through consumption of sheep and goats raw milk.

Copyright @ 2013, Ahvaz JundishapurUniversity of Medical Sciences; Published by Kowsar Corp. This is an open-access article distributed under the terms of the Creative Commons Attribution License, which permits unrestricted use, distribution, and reproduction in any medium, provided the original work is properly cited. 
eral domestic animals (11-13). Thus, due to the presence of tachyzoites in the milk, consumption of unpasteurized goat, sheep or cow milk and its products is a high-risk action (11). Occurrence of clinical toxoplasmosis in human has been attributed to consumption of unpasteurized goat milk (5, 14-16). Recently, due to the lack of studies involving the role of sheep milk as a potential source of toxoplasmosis transmission and based on the phylogenetic affinity between sheep and goats, several studies were carried out on ovine milk to determine the role of ovine milk as a potential source of toxoplasmosis transmission $(17,18)$.

\section{Objectives}

Cattle, sheep and goat are the most important meat and milk producing animals In Iran (19) and T. gondii is one of the most prevalent protozoan parasites in this country (20). Due to the economic importance of the disease as well as the paucity of published reports about the $T$. gondii presence in the milk of sheep and goats and also a health concern due to neonatal complications in Iran, it is necessary to investigate the prevalence of T. gondii infection in the milk of producing animals especially sheep and goats which supply the main sources of milk for local consumption in North West of Iran.

The aim of the present study was to detect of $T$. gondii DNA in the milk of infected sheep and goats. Moreover, PCR-restriction fragment length polymorphism (RFLP) was used for identification of the B1 gene polymorphism among T. gondii parasites obtained from sheep and goats milk samples of North West of Iran.

\section{Materials and Methods}

\subsection{Sampling}

625 small ruminants (including: 345 sheep and 280 goats) were randomly selected from various regions of North-West of Iran, From March to September 2011. Milk samples were taken manually by milking the teats which had previously been disinfected with iodine alcohol and use of gloves during manipulation. The samples were kept under refrigeration and transferred in sterile microtubes to the laboratory of Parasitology, Faculty of Veterinary Medicine, Urmia University, for molecular analysis.

\subsection{PCR Amplification}

Total DNA was extracted from each sheep and goat milk sample using a Genomic DNA purification kit (Fermentas, Germany), adjusted to a total volume of $200 \mu \mathrm{L}$ in TE buffer and stored at $-20^{\circ} \mathrm{C}$ until the usage time. Amplification of the B1 gene of T. gondii was performed by sensitive and previously reported species-specific primers used to amplify a fragment of $529 \mathrm{bp}$ (21). The sequences of primers were as follows:

TOX4 (CGCTGCAGGGAGGAAGACGAAAGTTG)|

\section{TOX5 (CGCTGCAGACACAGTGCATCTGGATT)}

The PCR reaction was performed in a $50 \mu \mathrm{L}$ total reaction volume containing $5 \mu \mathrm{L}$ of 10X PCR buffer, $2 \mathrm{mM}$ $\mathrm{MgCl}_{2}, 250 \mu \mathrm{M}$ of each of the four deoxynucleotide triphosphates, $1.25 \mathrm{U}$ Taq DNA polymerase (Fermentas, Germany), $50 \mathrm{pmol}$ of each primer and $5 \mu \mathrm{L}$ of the extracted DNA. The positive control for T. gondii was kindly provided by Razi Vaccine and Serum Research Institute (Tehran branch, Iran). Sterile water was served as negative control.

Cycling condition was $94^{\circ} \mathrm{C}$ for 7 minutes, followed by 33 cycles of 1 minute at $94^{\circ} \mathrm{C}, 1$ minute at $55^{\circ} \mathrm{C}$ and 1 minute at $72^{\circ} \mathrm{C}$ with a final step at $72^{\circ} \mathrm{C}$ for 10 minutes. Five microliters of each DNA sample were used as the template. PCR products were analyzed by $2 \%$ agarose gel electrophoresis followed by ethidium bromide staining and photography.

\subsection{RFLP of PCR Products}

The amplified products were digested with AluI restriction enzyme (Fermentas, Germany) as described by the manufacturer, and analyzed using 2\% agarose gel. Each digestion reaction was set up in a $20 \mu \mathrm{L}$ volume containing $2 \mu \mathrm{L}$ of the $10 \mathrm{X}$ reaction buffer, $10 \mu \mathrm{L}$ of PCR products and $10 \mathrm{U}$ of the restriction enzyme. The digestion mixture was incubated at $37^{\circ} \mathrm{C}$ for 2 hours.

\section{Results}

\subsection{Identification of T. gondii in the Milk Samples}

All obtained milk samples were examined by PCR. The results showed that $16(4.63 \%)$ sheep and $3(1.07 \%)$ goats milk samples were infected (Figure 1).

Figure 1. PCR-Amplified Products Using T. gondii Specific Primers

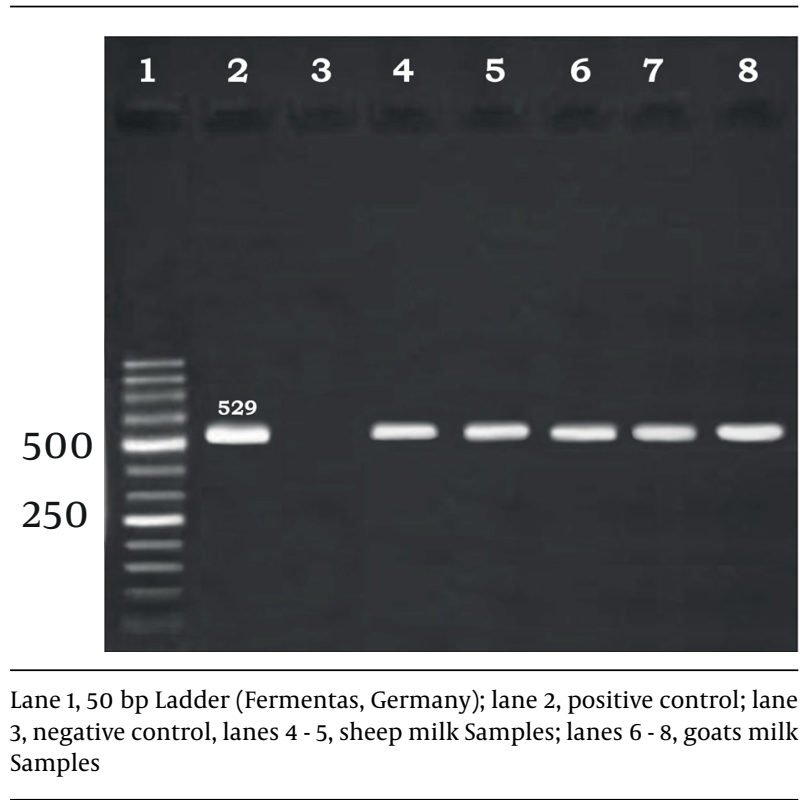


Tavassoli Met al.

\subsection{RFLP of T. gondii B1 Gene Amplified Region Isolated From Animals}

A single RFLP profile, expected three fragments (364 bp, $87 \mathrm{bp}$ and $78 \mathrm{bp}$ ), was yielded from PCR positive milk samples using AluI restriction enzyme (Figure 2).

Figure 2. RFLP Patterns of Amplified 529 bp PCR Products of T. gondi Generated Using AluI

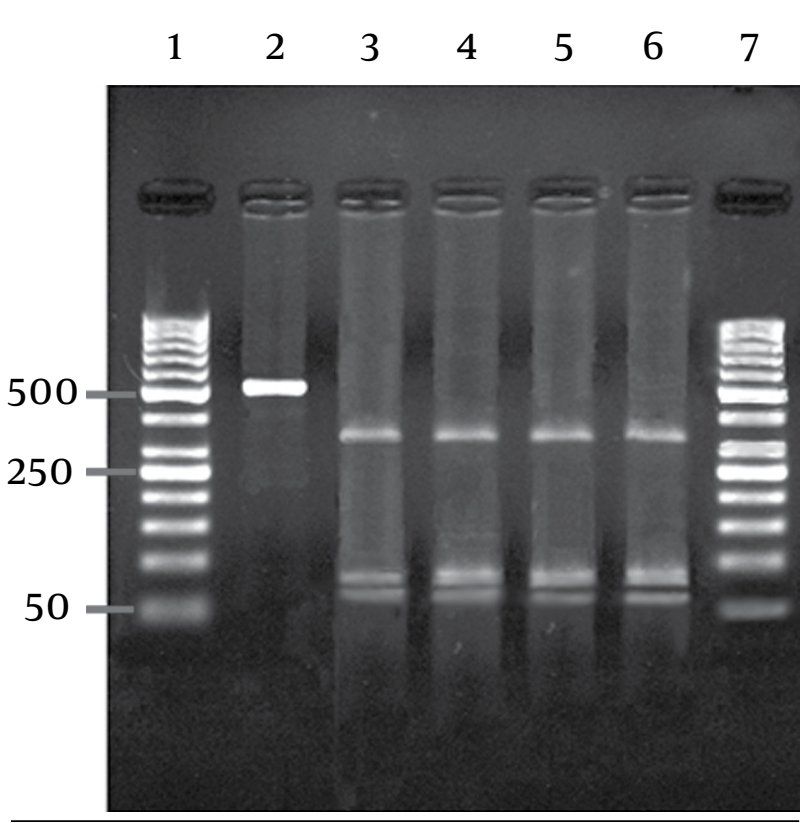

Lane 1, 50 bp ladder (Fermentas, Germany); lane 2, undigested PCR product, lanes $3-4$, digested PCR products of sheep milk; lanes 5 - 6, digested PCR products of goats milk

\section{Discussion}

Sheep and goats are economically important in many countries, because of production of milk and meat (22). Consumption of unpasteurized goat milk is a source of infection for humans $(5,15,16)$. Chiari and Neves had reported the excretion of tachyzoit in the milk of naturally infected goats (15). During an acute infection in goats, tachyzoit of $T$. gondii may be excreted in the milk and become a possible source of human infection $(5,15)$. In addition, physiologic decrease in the peripartum immunity may lead to reactivation of $T$. gondii cyst and excretation of parasite tachyzoites in the milk (18). Tachyzoites are generally not considered as important sources of oral transmission of $T$. gondii because they are sensitive to proteolytic enzymes of the milk and are thought to be immediately destroyed by the gastric juice $(11,13)$. Presumably, a part of tachyzoites is excreted in the milk which is not destroyed by the gastric juice due to its rapid passage through this digestive compartment (23).

Although pasteurization will kill $T$. gondii in milk, unpasteurized raw milk and goat cheeses made out of it can be among the sources of $T$. gondii infection (7). Hiramoto et al. has shown that consumption of unpasteurized milk or fresh cheese is the major source of contamination by this parasite in rural areas (24). Based on the similarity between sheep and goats, ovine milk can be a potential source of infection to humans (18). There are several reports on PCR method usage for detection of T. gondii DNA in the milk of sheep and goats. Camossi et al. identified $T$. gondii DNA in seven milk samples of 20 naturally infected sheep by PCR. They demonstrated the presence of T. gondii DNA in the milk (18). In another study by Fusco et al. the transmission potential of ovine milk and dairy products was presented. They detected the parasite DNA in 3.4\% of total analyzed milk samples of sheep by PCR (17).

In this study, T. gondii DNA was found in 16 (4.63\%) and 3 (1.07\%) milk samples from 345 and 280 naturally infected sheep and goats, respectively. Lower infection rates in goats compared to those in sheep may be attributed to the differences in susceptibility to T. gondii and the feeding habits of the animals (25). The presence of $T$. gondii DNA, detected by molecular analysis, raises the possibility that this parasite is transmitted through consumption of raw milk and its non-pasteurized derivatives which are highly-concerned result for the public health (18).

RFLP is a technique in which organism may be differentiated by analysis of the pattern derived from the cleavage of its DNA. Diversity of the generated patterns can be used to differentiate species and even strains from each other. PCR-RFLP has been used to identify the genotypes of $T$. gondii isolates (26). There are three major genotypes (type I, type II, and type III) of T. gondii. These genotypes differ in their pathogenicity and prevalence. Type III is more common in animals than in human toxoplasmosis (27). Zia-Ali et al. found four isolates of T. gondii from adult sheep in Iran, two of which were Type II and two were Type III. Type II was the predominant lineage of the strains isolated from sheep (20).

To date, No Type I isolate of T. gondii has been found in sheep (4). In a study on T. gondii infection in domestic animals of Urmia by PCR - RFLP, Tavassoli et al. showed that sheep and horse were infected with the same strain of $T$. gondii (28). As PCR-RFLP genotyping is simple and costeffective compared to DNA sequencing, it is considered as a rapid and practical tool for identification and estimation of genetic diversity in T. gondii (29). In this study, the PCR-RFLP results indicated that a strain of $T$. gondii exists in the study area, and there is a need for more investigations regarding the distribution of different strains in other parts of the country.

In conclusion, our findings demonstrated the presence of T. gondii DNA in the milk of sheep and goats. Presence of T. gondii DNA raises the possibility that this parasite is transmitted through consumption of raw sheep and goats' milk. Since sheep and goats are the most important milk sources in Iran, there may be a high risk of contamination through milk from these hosts due to their 
susceptibility to the infection. Therefore, further investigations are necessary to collect more information on the prevalence of T. gondii DNA in milk-producing animals to apply effective control strategies against toxoplasmosis.

\section{Acknowledgements}

Authors would like to thank Mr. A. Kazemnia for his technical assistance. We would like to sincerely thank the members of the Faculty of Veterinary Medicine and Urmia University Research Council for the approval and support of this research.

\section{Authors' Contribution}

Study concept and design: Tavassoli, Esmaeilnejad, Malekifard. Analysis and interpretation of data:Tavassoli, Soleimanzadeh, Dilmaghani. Drafting of the manuscript: Tavassoli, Esmaeilnejad, Malekifard.

\section{Financial Disclosure}

The authors declare no financial disclosure.

\section{Funding/Support}

This research was financially supported by Urmia University Research Council.

\section{References}

1. Smith RJ. Saving the diabetic foot. J Natl Med Assoc 2000;92(8):405-10.

2. Dubey JP. Toxoplasmosis - a waterborne zoonosis. Vet Parasitol. 2004;126(1-2):57-72.

3. Buxton D, Maley SW, Wright SE, Rodger S, Bartley P, Innes EA. Toxoplasma gondii and ovine toxoplasmosis: new aspects of an old story. Vet Parasitol. 2007;149(1-2):25-8.

4. Dubey JP. Toxoplasmosis in sheep--the last 20 years. Vet Parasitol. 2009;163(1-2):1-14

5. Sacks JJ, Roberto RR, Brooks NF. Toxoplasmosis infection associated with raw goat's milk. JAMA. 1982;248(14):1728-32.

6. Webster IP, McConkey GA. Toxoplasma gondii-altered host behaviour: clues as to mechanism of action. Folia Parasitol (Praha). 2010;57(2):95-104

7. Dubey JP. Toxoplasmosis of Animals and Humans. 2 edUSA, Florida: CRC Press, Boca Raton; 2009.

8. Jittapalapong S, Sangvaranond A, Pinyopanuwat N, Chimnoi W, Khachaeram W, Koizumi S, et al. Seroprevalence of Toxoplasma gondii infection in domestic goats in Satun Province, Thailand. Vet Parasitol. 2005;127(1):17-22.

9. Flegr J, Hrdy I. Influence of chronic toxoplasmosis on some human personality factors. Folia Parasitol (Praha).1994;41(2):122-6.

10. Chiari CA, Lima WS, Antunes CMF, Lima JD. [Soroepidemiology of toxoplasmose goats in Minas Gerais]. Arq Bras Med Vet Zootec. 1987;39:587-609.
11. Dubey JP. Re-examination of resistance of Toxoplasma gondii tachyzoites and bradyzoites to pepsin and trypsin digestion. Parasitology. 1998;116 ( Pt 1):43-50.

12. Tenter AM, Heckeroth AR, Weiss LM. Toxoplasma gondii: from animals to humans. Int J Parasitol. 2000;30(12-13):1217-58.

13. Powell CC, Brewer M, Lappin MR. Detection of Toxoplasma gondii in the milk of experimentally infected lactating cats. Vet Parasitol. 2001;102(1-2):29-33.

14. Riemann HP, Meyer ME, Theis JH, Kelso G, Behymer DE. Toxoplasmosis in an infant fed unpasteurized goat milk. J Pediatr 1975;87(4):573-6.

15. Chiari Cde A, Neves DP. [Human toxoplasmosis acquired by ingestion of goat's milk]. Mem Inst Oswaldo Cruz. 1984;79(3):337-40.

16. Skinner LJ, Timperley AC, Wightman D, Chatterton JM, Ho-Yen DO. Simultaneous diagnosis of toxoplasmosis in goats and goatowner's family. Scand J Infect Dis. 1990;22(3):359-61.

17. Fusco G, Rinaldi L, Guarino A, Proroga YT, Pesce A, Giuseppina de $\mathrm{M}$, et al. Toxoplasma gondii in sheep from the Campania region (Italy). Vet Parasitol. 2007;149(3-4):271-4

18. Camossi LG, Greca-Junior H, Correa AP, Richini-Pereira VB, Silva RC, Da Silva AV, et al. Detection of Toxoplasma gondii DNA in the milk of naturally infected ewes. Vet Parasitol. 2011;177(3-4):256-61

19. Hamzavi Y, Mostafaie A, Nomanpour B. Serological Prevalence of Toxoplasmosis in Meat Producing Animals. Iran J Parasitol. 2007;2(1):7-11.

20. Zia-Ali N, Fazaeli A, Khoramizadeh M, Ajzenberg D, Darde M, Keshavarz-Valian H. Isolation and molecular characterization of Toxoplasma gondii strains from different hosts in Iran. Parasitol Res. 2007;101(1):111-5.

21. Homan WL, Vercammen M, De Braekeleer J, Verschueren H. Identification of a 200-to 300 -fold repetitive 529 bp DNA fragment in Toxoplasma gondii, and its use for diagnostic and quantitative PCR. Int J Parasitol. 2000;30(1):69-75.

22. Ragozo AM, Pena HF, Yai LE, Su C, Gennari SM. Genetic diversity among Toxoplasma gondii isolates of small ruminants from Brazil: novel genotypes revealed. Vet Parasitol. 2010;170(3-4):307-12.

23. Bart JM, Morariu S, Knapp J, Ilie MS, Pitulescu M, Anghel A, et al. Genetic typing of Echinococcus granulosus in Romania. Parasitol Res. 2006;98(2):130-7.

24. Hiramoto RM, Mayrbaurl-Borges M, Galisteo AJ, Jr, Meireles LR, Macre MS, Andrade HF, Jr. Infectivity of cysts of the ME-49 Toxoplasma gondii strain in bovine milk and homemade cheese. Rev Saude Publica. 2001;35(2):113-8.

25. Bahrieni M, Fasihi Harandi M, Beigzadeh M, Kamyabi H, Zia-Ali N Risk Factors Analysis Associated with Seropositivity to Toxoplasma gondii in Sheep and Goats in Southeastern Iran Using Modified Agglutination Test (MAT). Iran J Parasitol. 2008;3(1):38-43.

26. Quan JH, Kim TY, Choi IU, Lee YH. Genotyping of a Korean isolate of Toxoplasma gondii by multilocus PCR-RFLP and microsatellite analysis. Korean J Parasitol. 2008;46(2):105-8.

27. Howe DK, Sibley LD. Toxoplasma gondii comprises three clonal lineages: correlation of parasite genotype with human disease. $J$ Infect Dis.1995;172(6):1561-6.

28. Tavassoli M, Tabatabaii M, Esmailnejad B, Javadi S, Kazemnia A, Mardani K. [Investigation on Toxoplasma gondii infection in domestic animals in Urmia by PCR and RFLP]. Vet J (Pajouhesh 8 Sazandegi). 2010;83:51-61.

29. Su C, Zhang X, Dubey JP. Genotyping of Toxoplasma gondii by multilocus PCR-RFLP markers: a high resolution and simple method for identification of parasites. Int J Parasitol. 2006;36(7):841-8. 